\title{
MODEL PEMBELAJARAN BERBASIS BALANCED LITERACY APPROACH BERMUATAN NILAI-NILAI KARAKTER UNTUK PEMBELAJARAN LITERASI DASAR DI KELAS AWAL
}

\author{
Supartinah, Sumardi, dan Banu Setyo Adi \\ Universitas Negeri Yogyakarta \\ e-mail: supartinah@uny.ac.id
}

\begin{abstract}
Abstrak
Artikel ini memaparkan hasil penelitian dan pengembangan model pembelajaran berbasis balanced literacy approach untuk pembelajaran literasi dasar siswa kelas awal sekolah dasar. Penelitian Research and Development $(R \& D)$ yang telah diterapkan mengadopsi dari model pengembangan versi Borg and Gall (1989). Penelitian telah dilaksanakan melalui tahap studi pendahuluan dilakukan dengan menerapkan pendekatan deskriptif kualitatif; mengembangkan prototype model pembelajaran, dilanjutkan validasi ahli materi dan pembelajaran; evaluasi yang dilakukan dengan ujicoba implementasi model di kelas I, II, dan III. Teknik pengumpulan data adalah angket, observasi, wawancara. Analisis data dengan deskriptif kuantitatif dan kualitatif. Model pembelajaran yang dikembangkan terdiri atas 4 tahap kegiatan pembelajaran, yaitu tahap I eksplorasi sumber informasi, tahap II penerapan strategi berimbang, tahap III penyajian informasi, dan tahap IV refleksi. Hasil validasi model yang dikembangkan dari ahli materi menunjukkan rerata skor 3,6 (kategori sangat baik) dan rerata skor validasi ahli pembelajaran sebesar 3,6 (kategori sangat baik). Hasil ujicoba implementasi model menunjukkan capaian rerata hasil belajar di kelas I sebesar 91 dari rerata kemampuan awal sebesar 84. Rerata hasil belajar di kelas II sebesar 82 dari rerata kemampuan awal 75, dan di kelas III menunjukkan rerata hasil belajar 74 dari rerata kemampuan awal sebesar 64. Hasil angket respon siswa terhadap implementasi model pembelajaran di kelas I menunjukkan rerata skor 3,3 (kategori sangat baik), kelas II menunjukkan rerata skor 3,7 (kategori sangat baik), dan kelas III menunjukkan rerata skor 3,5 (kategori sangat baik). Secara umum, siswa dalam mengikuti pembelajaran sangat aktif karena dalam pembelajaran ini memberikan berbagai kegiatan literasi yang kreatif dan bervariasi.
\end{abstract}

Kata Kunci: model pembelajaran; literasi; kelas awal

\section{MODEL BASED LEARNING BALANCED LITERACY APPROACH WITH CHARACTER VALUES FOR LEARNING BASIC LITERACY IN THE EARLY GRADE}

\begin{abstract}
This article presents the results of the research and development of model-based learning balanced literacy approach to learning basic literacy students grades early elementary school. Research Research and Development $(R \& D)$ had applied to adopt the model of the development version of the Borg and Gall (1989). Research has been carried out through the stage of preliminary studies done by implementing a descriptive qualitative approach; develop a prototype model of learning, validation of learning material and experts; the evaluation is done by trial model implementation in class I, II, and III. The technique of data collection is the question form, observation, interviews. Data analysis with quantitative and qualitative descriptive. The learning model developed consists of 4 stages learning activities, namely phase I exploration of information resources, phase II implementation strategy balanced, presenting information, phase III and phase IV of the reflection. The results of the validation of the model developed from expert material showed
\end{abstract}


a mean score of 3.6 (very good) and the mean score of 3.6 learning expert validation (category very well). The results of the trial implementation of the model shows the average results of close study in class I of 91 of the initial capabilities of average 84. Average results of learning in class II of 82 of average ability early, and 75 in the class III indicates learning outcomes 74 average of average ability early registration 64 . The results of the now student response towards the implementation of the model of learning in class I showed a mean score of 3.3 (the category very well), class II indicates the average score of 3.7 (very good), and a class III indicates the average score 3.5 (very good). In General, students follow a very active learning, because in this study provide a variety of literacy activities are creative and varied.

Keywords: learning model; literacy; early grade

\section{PENDAHULUAN}

Perkembangan ilmu pengetahuan dan teknologi sekarang ini sangat pesat, cepat, dan tidak berbatas, ibaratnya, berbagai bentuk informasi global dapat dibaca atau diketahui hanya dengan satu sentuhan jari saja. Dampak dari perkembangan tersebut, ada yang positif dan ada pula yang negatif. Salah satu yang positif adalah masyarakat telah dimanjakan dengan berbagai kemudahan mengakses berbagai macam informasi untuk membantu memecahkan berbagai permasalahan dalam segala aspek ke-hidupan. Adapun salah satu dampak negatifnya adalah pemanfaatan kecanggihan iptek untuk hal-hal yang merugikan orang lain, misalnya menyebar berita hoax, fitnah, menyesatkan, pornografi dan lain sebagainya.

Siswa sekolah dasar, sebagai salah satu bagian dari anggota masyarakat, juga mampu memanfaatkan berbagai jenis gadget untuk mengakses informasi yang ingin diketahuinya. Menyelesaikan berbagai tugas-tugas sekolah dapat dengan mudah didapatkan dengan bertanya "mbah google", meskipun ada beberapa informasi yang belum dapat dipertanggungjawabkan kebenarannya. Namun demikian, ada pula sebagian siswa sekolah dasar yang menjadi korban dari perkembangan kecanggihan Iptek tersebut.

Beberapa kasus penyimpangan nilai dan moral oleh siswa sekolah dasar mencuat dalam pemberitaan akhir-akhir ini. Dari permasalahan sopan santun, merokok, mencontek massal, sampai dengan cara bergaul dengan lawan jenis. Gambaran kenakalan siswa SD yang lain telah muncul dalam pemberitaan pembulian dan pelecehan yang dilakukan oleh siswa SD pada temannya yang termuat di Detik News (2015). Berita tersebut sangat mengejutkan dan mempri-hatinkan sebagai salah satu gambaran dampak dari kurangnya pendampingan dan penanaman nilai-nilai karakter, serta pengaruh dari berbagai tontonan dari berbagai sumber informasi tanpa batas.

Oleh karena itu, dibutuhkan bekal yang cukup untuk siswa dalam memahami dan memanfaatkan berbagai sumber informasi tersebut agar dapat memanfaatkannya, baik untuk kepentingan akademik maupun perkembangan karakternya. Selain kematangan karakter, salah satu bekal untuk menaklukkan berbagai dampak perubahan tersebut adalah membekali generasi muda dengan kemampuan literasi dasar yang baik. Kemampuan literasi dasar seperti yang dimaksud oleh Clay \& Ferguson, bukan sekedar kemampuan membaca dan menulis secara mekanik saja, namun dalam arti kemampuan untuk mendengarkan, berbicara, membaca, menulis, dan menghitung berkaitan dengan kemampuan analisis untuk memperhitungkan, mempersepsikan informasi, mengomunikasikan, serta menggambarkan informasi berdasar-kan pemahaman dan pengambilan kesimpulan pribadi (Wiedarti, dkk., 2016).

Pembekalan kemampuan literasi dasar dengan mengintegrasikan muatan nilai- nilai karakter sangat efektif jika diberikan sejak dini. Salah satunya melalui 
pembelajaran di kelas awal sekolah dasar, yakni kelas I, II, dan III. Hal ini penting sebagai dasar untuk melanjutkan pendidikan di jenjang kelas berikutnya. Jika pembekalan kemampuan literasi dasar di kelas awal tersebut tidak diberikan dengan baik, maka siswa akan sangat kesulitan untuk mengembangkan pengetahuannya.

Sejalan dengan hal tersebut, berdasarkan berita Kompas (Oktober 2016) pendidikan di sekolah dasar perlu mendapatkan perhatian yang lebih serius. Jumlah terbanyak siswa yang mengulang atau tidak naik kelas dan putus sekolah terjadi di SD. Lebih detail lagi, mengulang dan putus sekolah paling banyak dialami oleh siswa yang duduk di kelas awal atau kelas I-III. Berdasarkan ikhtisar Data Pendidikan 2015/2016 yang dikeluarkan Kementerian Pendidikan dan Kebudayaan, jumlah siswa yang mengulang atau tidak naik kelas tahun 2015 di SD mencapai 422.082 siswa. Jumlah siswa mengulang di kelas I tertinggi, yakni 194.967 siswa. Di kelas II jumlahnya 89.561 siswa, sedangkan di kelas III angka 65.493 siswa. Sementara jumlah siswa putus sekolah di SD tahun 2015 tercatat 68.066 siswa $(0,26$ persen dari total 25.885.053 siswa SD). Jumlah siswa SD yang putus sekolah kelas I terbanyak, yakni 16.447 siswa, sedangkan di kelas II jumlahnya 12.714 siswa. Menguatkan permasalahan tersebut, hasil penelitian EGRA (Early Grade Reading Assessment) tahun 2012 di 7 Provinsi mitra Prioritas di Indonesia yang melibatkan 4323 peserta didik kelas 3 juga menunjukkan bukti bahwa $50 \%$ peserta didik dapat membaca (melek huruf). Akan tetapi, dari jumlah tersebut hanya setengahnya yang benarbenar memahami isi bacaan yang dibacanya (USAID, 2015).

Kenyataan tersebut, diduga karena lemahnya pembelajaran literasi dasar, khususnya pembiasaan membaca dan menulis karena kemampuan literasi tersebut sangat dibutuhkan siswa untuk membaca, mengerti, dan merespon berbagai informasi bidang ilmu atau mata pelajaran yang kompleks. Hingga pada akhirnya, mengurangi angka tidak naik kelas bagi siswa kelas awal.

Berdasarkan permasalahan di atas, tulisan ini akan memaparkan hasil penelitian yang memberikan solusi dari masalah tersebut, yaitu pengembangan model pembelajaran berbasis balanced literacy approach bermuatan nilai-nilai karakter untuk pembelajaran literasi dasar siswa kelas awal sekolah dasar. Model ini diharapkan dapat digunakan sebagai pembiasaan dan pembelajaran literasi yang bermuatan nilai karakter yang disesuaikan dengan perkembangan dan karakteristik siswa kelas I, II, dan III sekolah dasar. Muatan nilai karakter dalam model pembelajaran ini dimaksudkan untuk pembiasaan bersikap dan berperilaku baik dalam kehidupan sehari-hari. Muatan nilai karakter akan tampak dalam muatan materi dan teks bacaan serta langkah-langkah penerapan-nya. Nilai-nilai itu akan menggunakan sumber dari berbagai permasalahan yang sangat dekat dengan kehidupan sehari-hari siswa.

Masyarakat dengan kemampuan literasi yang baik merupakan modal dasar bagi suatu negara untuk melaksanakan pembangunan di berbagai bidang untuk menuju kesejahteraan hidup baik individu maupun masyarakat. Oleh karena itu, masyarakat yang literat sangat penting dalam menyumbang kearah kemajuan suatu negara. Kemampuan literasi tersebut meliputi tanggapan, pemahaman, dan kegiatan kehidupan sehari-hari yang tersusun dan diaplikasikan melalui kegiatan pembelajaran berkelanjutan. Kemampuan ini melibatkan kegiatan mengumpulkan pengetahuan yang mengarahkan seseorang untuk memahami dan menggunakan bahasa yang tepat sesuai situasi sosial.

Kemampuan literasi mempunyai definisi yang meliputi 1) kemampuan untuk memahami informasi, baik lisan maupun tertulis, 2) kemampuan untuk mengomunikasikan apa yang diketahui melalui berbicara dan menulis, 3) kemampuan untuk berbicara dengan jelas, tepat, dan logis, 4) kemampuan untuk menulis dengan lancar, mengomunikasi- 
kan ide-ide kunci atau penting, dan 5) memiliki tujuan berkomunikasi (Klein, Peterson, \& Simington, 1991).

Berdasarkan uraian tersebut, kemampuan literasi bukanlah kemampuan alamiah yang serta merta didapat oleh seseorang sebagai bawaan sejak lahir, namun merupakan kemampuan yang harus diajarkan. Oleh karena itu, siswa kelas awal sekolah dasar membutuhkan pendampingan dan bimbingan khusus untuk dapat menguasai kemampuan literasi tersebut. Dengan bekal kemampuan literasi yang baik, maka sangat mudah bagi siswa untuk membaca, mengerti, memahami, dan merespon berbagai informasi bidang studi atau matapelajaran yang kompleks. Di masa sekarang ini, pengertian literasi secara lebih luas tersebut dapat disebut sebagai literasi informasi.

Sejalan dengan uraian di atas, Clay \& Ferguson (Wiedarti, dkk., 2016) menguraikan bahwa komponen literasi informasi terdiri atas literasi dini, literasi dasar, literasi perpustakaan, literasi media, literasi teknologi, dan literasi visual. Lebih lanjut dijelaskan bahwa kemampuan literasi dasar adalah kemampuan untuk mendengarkan, berbicara, membaca, menulis, dan menghitung berkaitan dengan kemampuan analisis untuk memperhitungkan, mempersepsikan informasi, mengkomunikasikan, serta menggambarkan informasi berdasarkan pemahaman dan pengambilan kesimpulan pribadi.

Dalam tulisan ini, kemampuan literasi dasar lebih dikhususkan pada kemampuan membaca dan menulis sebagai bekal siswa kelas awal sekolah dasar dalam mempersepsikan berbagai informasi, mengomunikasikan, dan menggambarkannya informasi berdasarkan pemahaman dan simpulannya sendiri.

Balanced literacy approach atau dapat diartikan sebagai pendekatan literasi berimbang merupakan pendekatan pembelajaran yang mendasarkan pada tinjauan literasi secara luas dengan mengkombinasikan praktik terbimbing, pembelajaran kolabaratif, sampai dengan aktivitas membaca dan menulis secara mandiri
(Tompkins, 2010). Pendekatan literasi berimbang merupakan konsep pembelajaran yang memadukan pendekatan phonic dan whole language untuk menerapkan pembelajaran terbaik dalam pengembangan kemampuan membaca dan menulis.

Berdasakan paparan di atas, pendekatan literasi berimbang tersebut merupakan salah satu pendekatan yang tepat untuk mengatasi permasalahan kemampuan literasi dasar siswa kelas awal. Hal itu karena setiap siswa mempunyai kemampuan yang berbeda satu sama lain, sehingga perlu penanganan yang berbeda, dengan memanfaatkan berbagai program yang bervariasi dengan porsi yang seimbang.

Adapun karakteristik pendekatan Balanced literacy approach menurut Tompkins (2010) adalah 1) literasi melibatkan membaca dan menulis, 2) bahasa lisan terintegrasi dengan membaca dan menulis, 3) pembelajaran membaca meliputi aktivitas kesadaran fonemik, phonics, kelancaran, kosa kata, dan pemahaman, 4) pembelajaran menulis meliputi proses penulisan, kualitas penulisan yang baik untuk mengkomunikasikan ide-ide secara efektif, dan ejaan, tata bahasa, dan tanda baca untuk membuat ide-ide lebih mudah dibaca, 5) membaca dan menulis digunakan sebagai alat untuk konten pembelajaran, 6) strategi dan keterampilan diajarkan secara eksplisit dan bertahap, 7) siswa bekerja sama dan berbicara dengan teman sekelas, dan 8) siswa lebih termotivasi dan terlibat aktif ketika berpartisipasi dalam kegiatan pembelajaran.

Model pembelajaran yang telah dikembangkan berpedoman pada karakteristik balanced literacy approach tersebut dengan mengintegrasikan nilai-nilai karakter dalam setiap langkah-langkah kegiatan dan materi pembela-jarannya. Sejalan dengan paparan ini, menurut Pearson, et al. (2007) mema-parkan bahwa untuk mewujudkan pembelajaran literasi yang seimbang diperlukan proses yang kompleks yang mensyaratkan fleksibitas 
dan seni berorkestrasi dari berbagai macam aspek literasi secara kontekstual dan konseptual. Berdasarkan hal itu, sangatlah penting mendesain pembelajaran literasi yang variatif, menyenangkan, dan sesuai dengan kebutuhan dan kemampuan siswa kelas awal sekolah dasar, sehingga dapat membantu siswa menyelesaikan tugas belajarnya tanpa harus tinggal kelas atau putus sekolah.

Mendukung hal tersebut, Tompkins (2010) menyampaikan bahwa untuk mewujudkan pendekatan berimbang dalam pembelajaran literasi diperlukan integrasi komponen-komponen yang meliputi membaca, phonic, keterampilan literasi, strategi membaca dan menulis, kosakata, pemahaman, literatur, konten pembelajaran, bahasa lisan, menulis, dan ejaan. Komponen-komponen tersebut harus dapat diorkestrasi dengan baik agar tujuan pembelajaran literasi dapat tercapai.

Manusia sebagai makhluk sosial menjadi penghasil sistem berpikir, nilai, moral, norma, dan keyakinan; akan tetapi juga dalam interaksi dengan sesama manusia dan alam kehidupan, manusia diatur oleh sistem berpikir, nilai, moral, norma, dan keyakinan yang telah dihasilkannya. Pendidikan merupakan upaya terencana dalam mengembangkan potensi siswa, sehingga mereka memiliki sistem berpikir, nilai, moral, dan keyakinan yang diwariskan masyarakat-nya dan mengembangkan warisan tersebut ke arah yang sesuai untuk kehidupan masa kini dan masa mendatang (Balitbang, 2010). Warisan tersebut, salah satunya juga karakter mulia. Karakter mulia berarti individu mempunyai pengetahuan tentang potensi dirinya yang ditandai dengan nilainilai seperti reflektif, percaya diri, rasional, logis, kritis, analitis, dan masih banyak nilai-nilai kebaikan yang berkembang dalam dirinya. Untuk mengembangkan nilai-nilai karakter yang baik tersebut, perlu upaya yang dilakukan secara terus menerus dan hasilnyapun tidak serta merta dapat terwujud. Oleh karena itu, perlu proses untuk dapat mewujudkannya, salah satunya melalui sistem pendidikan, lebih spesifik, melalui proses pembelajarannya (Sofan, dkk, 2011).

Sejalan dengan hal tersebut, Sofan, dkk (2011) mengemukakan bahwa pendidikan karakter dapat dimaknai sebagai segala sesuatu yang dilakukan guru yang mampu mempengaruhi karakter siswa, sehingga dalam kegiatan ini, guru dapat membantu membentuk watak siswa. Dalam setiap proses kegiatan pembelajaran, baik di dalam maupun di luar kelas, sosok guru akan menjadi sosok yang langsung maupun tidak akan selalu dilihat, diperhatikan, dan didengar oleh siswa. Setiap perilaku guru akan menjadi teladan bagi siswanya, seperti cara mengajarnya, cara bicaranya, cara berpakaian, cara bertoleransi, dan masih banyak yang lainnya.

Termasuk dalam pembelajaran literasi, juga sangat membutuhkan keteladanan guru dalam berbahasa dan berkomunikasi lisan dan tulis dengan baik dan benar, serta sesuai dengan nilai-nilai karakter. Terkait dengan hal itu, Lickona (Zuchdi, 2011) menyebutkan sepuluh nilai utama yang bisa ditanamkan dalam pembelajaran, yaitu kebijaksanaan, keadilan, daya tahan, kontrol diri, cinta, sikap positif, kerja keras, kepribadian yang utuh, perasaan berterimakasih, dan kerendahan hati. Dalam pembelajaran literasi di kelas awal, sangatlah tepat jika siswa diajarkan keterampilan berbahasa dengan muatan karakter tersebut sebagai pondasi awal dalam melanjutkan perkem-bangan sosial emosionalnya ke tahap selanjutnya.

\section{METODE}

Tulisan ini merupakan hasil penelitian Research and Development $(R \& D)$ yang mengadaptasi model pengembangan versi Borg and Gall (1989). Prosedur penelitian yang telah dijalani adalah pertama studi pendahuluan dilakukan dengan menerapkan pendekatan deskriptif kualitatif. Kegiatan yang dilakukan adalah dengan studi literatur, studi lapangan tentang keterkaitan antara Kompetensi Inti, Kompetensi Dasar, materi literasi (materi membaca dan menulis) yang ada di 
lapangan (kelas I, II, III sekolah dasar), serta identifikasi nilai-nilai karakter dan kesesuaiannya dalam pembelajaran literasi di kelas awal. Kedua, tahap mengembangkan prototype model pembelajaran berbasis balanced literacy approach bermuatan nilai-nilai karakter di kelas awal, dilanjutkan mengembangkan perang-kat rancangan pelaksanaan model pembelajaran, uji ahli pembelajaran dan ahli materi kemudian dilakukan revisi, dan ketiga, tahap evaluasi yang dilakukan ujicoba implementasi model pembelajaran berbasis balanced literacy approach untuk pembelajaran literasi dasar siswa kelas awal sekolah dasar. Pada akhirnya didapatkan model final.

Subjek ujicoba penelitian ini adalah siswa kelas awal sekolah dasar, yaitu kelas I, II, dan III di SDN Golo Yogyakarta. Responden melibatkan guru kelas I, II, III dan siswa kelas I, II, III. Subjek penelitian untuk validasi melibatkan 1 orang ahli materi dan 1 orang ahli pembelajaran. Ahli materi menvalidasi substansi materi literasi, sedangkan ahli pembelajaran menvalidasi sintaks model yang akan dikembangkan beserta perangkat implementtasinya. Tahapan proses ujicoba penelitian ini dilakukan di kelas I, II, III SDN Golo Yogyakarta. Penelitian ini telah dilaksanakan pada bulan April sampai dengan Oktober 2017.

Pengumpulan data dalam penelitian ini menggunakan berbagai teknik, yaitu angket, observasi, wawancara, dan studi dokumentasi sesuai dengan langkahlangkah kegiatan dalam penelitian. Teknik analisis data yang digunakan dalam penelitian ini adalah analisis deskriptif kuantitatif dan kualitatif. Data yang dianalisis meliputi data kelayakan model pembelajaran yang dikembangkan ahli bahasa dan ahli pembelajaran, serta respon yang diberikan oleh siswa kelas awal sebagai subjek uji coba.

\section{HASIL DAN PEMBAHASAN}

Kegiatan pengembangan model pembelajaran berbasis balanced literacy approach bermuatan nilai-nilai karakter untuk meningkatkan kemampuan literasi dasar siswa kelas awal SD, diawali dengan tahap studi pendahuluan, dilanjutkan studi pengembangan, dan diakhiri dengan kegiatan evaluasi. Hasil dari ketiga studi tersebut, diuraikan sebagai berikut.

Kegiatan dalam studi pendahuluan terdiri atas kegiatan pertama, yaitu studi literatur, analisis Kompetensi Inti, Kompetensi Dasar, muatan materi pembelajaran membaca dan menulis di kelas I, II, III berdasarkan kurikulum 2013. Kegiatan kedua adalah studi tentang kesesuaian nilainilai karakter dalam pembelajaran literasi. Kegiatan terakhir dalam studi pendahuluan adalah mendeskripsikan pembelajaran dan kemampuan membaca dan menulis di kelas awal secara faktual.

Sekolah dasar yang digunakan untuk studi pendahuluan mewakili 3 kabupaten/ kota, yaitu kabupaten Gunung Kidul, kabupaten Sleman, dan kota Yogyakarta. Masing- masing kabupaten dipilih 3 sekolah dasar yang mewakili kualitas sekolah dengan kategori kurang, sedang, dan baik berdasarkan capaian akademik dan fasilitas literasinya. Sekolah dasar di kabupaten Gunungkidul yaitu SD Negeri Playen IV, SD Negeri Wonosari Baru, dan SD Muhammadiyah Al Mujahidin. Sekolah dasar di kabupaten Sleman adalah SD Negeri Percobaan 3 Pakem, SD Negeri Pakem 1, dan SD Negeri Pakem 4. Adapaun sekolah dasar yang mewakili kota Yogyakarta adalah SD Negeri Gedongkiwo, SD Negeri Golo, dan SD Negeri Prawirotaman.

Berdasarkan studi pendahuluan diketahui data kemampuan membaca dan menulis siswa kelas awal di beberapa sekolah dasar sasaran penelitian adalah 229 siswa kelas I, terdapat $22 \%$ siswa belum dapat membaca dan menulis, 26\% siswa dalam kategori perlu bimbingan, dan 52\% siswa sudah dalam kategori mandiri. Berdasarkan wawancara dan angket terbuka, hal ini karena masih menjadi siswa baru transisi dari TK jadi masih kurang semanagat untuk belajar.

Sejumlah 243 siswa kelas II, terdapat $2 \%$ siswa belum dapat membaca dan 
menulis, $19 \%$ siswa masih perlu bimbingan, dan $80 \%$ siswa sudah mandiri. Hal ini menurut beberapa guru terkait dengan membaca yang sesuai dengan intonasinya. Lebih lanjut berdasarkan gambar di atas, masih terdapat sejumlah 242 siswa di kelas III semua sudah dapat membaca dan menulis atau $89 \%$ sudah dalam kategori mandiri, namun masih terdapat $10 \%$ siswa yang perlu bimbingan dalam membaca dan menulis. Hal ini menurut guru terkait dengan rendahnya pemahaman siswa terhadap isi bacaan.

Berdasarkan keadaan di atas, masih terdapat siswa kelas II yang belum dapat membaca dan menulis, serta masih ada siswa kelas III yang masih perlu bimbingan dalam membaca dan menulis. Hal ini dapat disimpulkan bahwa siswa yang belum dapat membaca dan menulis yang asumsinya akan sangat kesulitan menyelesaikan tugas-tugas belajarnya, akan tetap naik kelas. Pada kelas berikutnya, dengan kondisi belum dapat membaca dan menulis, siswa dihadapkan pada tugas-tugas belajar pada tingkat yang lebih tinggi, sehingga kemungkinannya siswa akan semakin kesulitan mengikuti pelajaran- pelajaran yang lain. Oleh karena itu sangat diperlukan kreativitas dan bimbingan yang ekstra dari guru kelasnya.

Hasil studi pendahuluan terkait dengan hal di atas adalah bahwa mayoritas guru kelas I, II, dan III sudah memahami kemampuan literasi dasar yang dibutuhkan oleh siswa di kelas yang diampunya.

Berdasarkan angket terbuka, wawancara nonformal, dan observasi, mayoritas sekolah sudah berupaya untuk menyelenggarakan kegiatan literasi untuk mendukung peningkatan kemampuan literasi siswa di kelas awal, di antaranya adalah permainan merangkai kata melalui huruf yang diacak, scrambel huruf, permainan bisik kalimat, pojok baca, kegiatan 15 menit membaca sebelum KBM, membaca buku cerita, menyimak cerita inspiratif, kunjungan perpustakaan, dan menulis data buku di jurnal literasi.
Sumber bacaan yang digunakan guru adalah buku-buku cerita yang menarik bagi anak, baik dari segi warna, gambar dan tulisan, jurnal literasi, buku cerita, buku ensiklopedi, kumpulan dongen/ cerpen, kliping tentang materi tertentu, kamus, kumpulan puisi, buku besar, gambar yang sesuai dengan materi yang akan diajarkan, kartu huruf, kartu bilangan, kartu kata, buku bacaan yang sederhana, tulisantulisan/slogan, dan mading. Beberapa guru telah melakukan kegiatan evaluasi terhadap kegiatan literasi yang telah diselenggarakannya, yaitu dengan tugastugas portofolio, menuliskan kembali atau meringkas cerita, membuat karya baik puisi, cerpen, dari kegiatan membaca, anak maju satu persatu untuk menghafalkan tugas yang diberikan. Bagi anak yang belum hafal agar membaca kembali dan menghafalkannya, mengada-kan tes lisan, ulangan harian, juga dengan observasi.

Dari kegiatan literasi yang telah diselenggarakan, menurut beberapa guru masih terdapat kekurangan. Di antaranya yaitu kurangnya sumber bacaan yang beragam, kontrol guru pada masing-masing siswa belum bisa optimal, siswa belum terbiasa meringkas bacaan, mengurangi jam pelajaran, kurangnya peralatan yang menyebabkan siswa kurang tertarik, siswa lebih suka dibacakan daripada membaca sendiri, terbatasnya waktu dan tim yang membantu kegiatan literasi, beberapa siswa masih ketinggalan dengan kemampuan teman-temannya.

Berdasarkan hasil dari studi pendahuluan tersebut, penelitian ini berusaha mengatasi permasalahan dengan mengembangkan prototipe model pembelajaran literasi yang efektif untuk meningkatkan kemampuan literasi dasar siswa sekolah dasar. Berdasarkan hasil identifikasi kemampuan literasi dasar dan muatan materi, maka tingkatan kompetensi/kemampuan literasi dasar dan tingkatan muatan materi utama yang digunakan sebagai dasar pengembangan prototipe model adalah sebagai berikut. 
Tabel 1. Kemampuan Dasar Literasi, Materi Utama, dan Nilai Karakter di Kelas Awal

\begin{tabular}{|c|c|c|}
\hline $\begin{array}{l}\text { Kemampuan } \\
\text { Dasar Literasi }\end{array}$ & Materi Utama & $\begin{array}{c}\text { Nilai } \\
\text { Karakter }\end{array}$ \\
\hline $\begin{array}{l}\text { Menyimak Berbicara } \\
\text { Membaca Menulis } \\
\text { Berhitung } \\
\text { Memperhitungkan } \\
\text { Mempersepsikan } \\
\text { informasi } \\
\text { Menyajikan informasi } \\
\text { berdasarkan } \\
\text { pemahaman }\end{array}$ & $\begin{array}{l}\text { - Teks pendek sederhana dengan ejaan yang } \\
\text { tepat (huruf kapital dan tanda baca, kosakata } \\
\text { baku, kalimat efektif)) dari berbagai sumber } \\
\text { informasi berupa gambar, tulisan, lisan, } \\
\text { slogan sederhana, dan/atau syair lagu, dan } \\
\text { eksplorasi lingkungan } \\
\text { - Ungkapan dengan bahasa santun } \\
\text { - Puisi anak/ syair lagu, dongeng } \\
\text { - Bilangan sebagai suatu kumpulan objek } \\
\text { - Bilangan sampai dua angka dan nilai tempat } \\
\text { penyusun lambang bilangan dengan benda } \\
\text { konkret dalam kehidupan sehari-hari }\end{array}$ & $\begin{array}{l}\text { Jujur, } \\
\text { disiplin, } \\
\text { tanggung } \\
\text { jawab, } \\
\text { santun, } \\
\text { peduli, dan } \\
\text { percaya diri }\end{array}$ \\
\hline
\end{tabular}

Berdasar kajian teoretis, hasil studi pendahuluan, kemampuan membaca teks berbahasa Jawa siswa sekolah dasar, serta hasil diskusi dengan guru-guru, maka dikembangkan desain prototipe model pembelajaran literasi berbasis balanced literacy approach bermuatan nilai-nilai karakter yang berupa langkah-langkah pembelajaran.
Desain awal model pembelajaran yang dilengkapi dengan rancangan pembelajaran kemudian divalidasi oleh ahli materi dan ahli pembelajaran. Validasi menunjukkan hasil dalam kategori sangat baik. Saran yang disampaikan oleh para ahli telah diakomodasi oleh peneliti sebagai bahan perbaikan. Hasil perbaikan prototipe model pembelajaran sebagai berikut.

Tabel 2. Desain Akhir Model Pembelajaran Berbasis Balanced Literacy Approach Bermuatan Nilai-nilai Karakter untuk Kelas Awal Sekolah Dasar

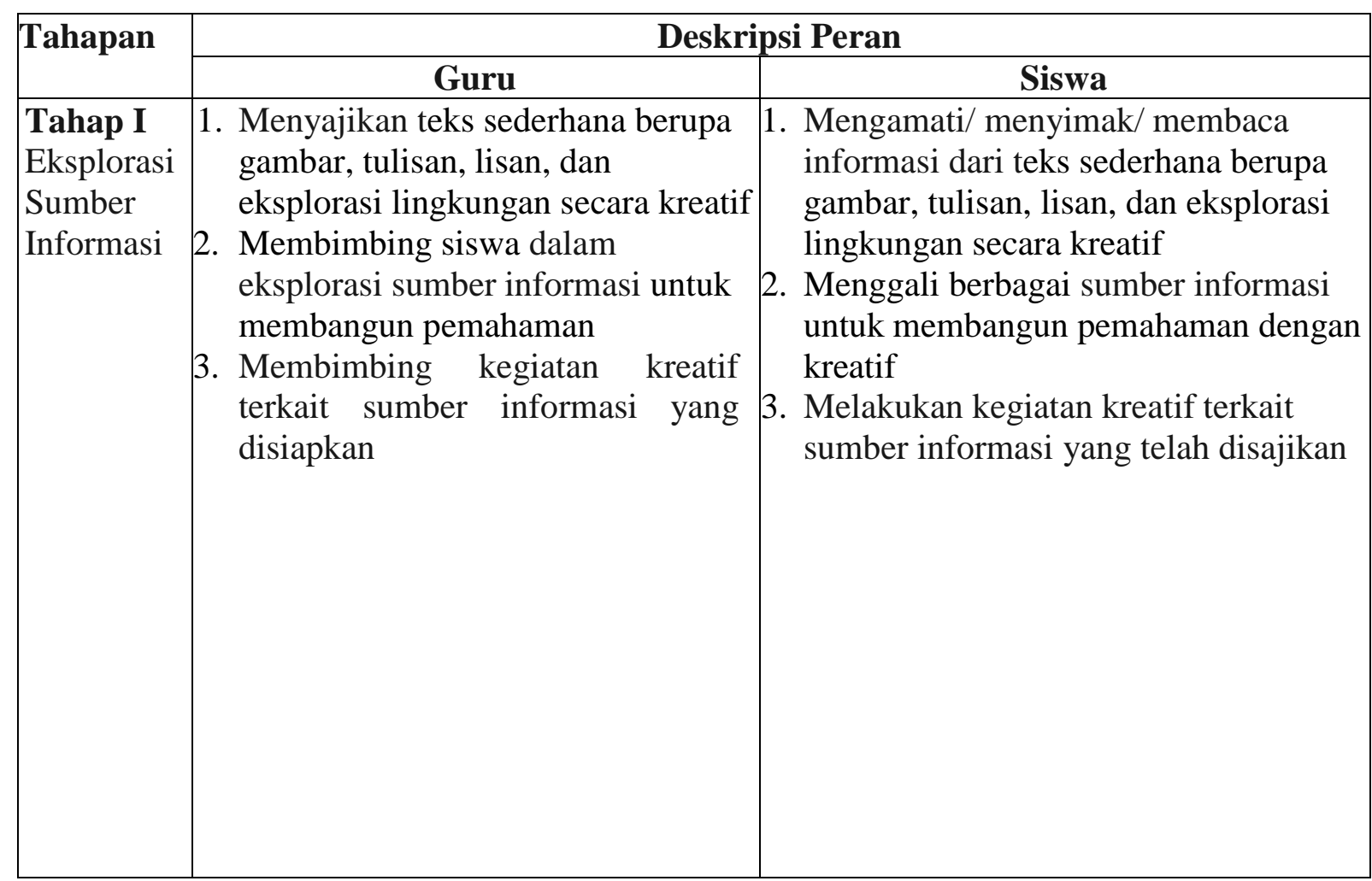




\begin{tabular}{|c|c|c|}
\hline \multirow[t]{2}{*}{ Tahapan } & \multicolumn{2}{|c|}{ Deskripsi Peran } \\
\hline & Guru & Siswa \\
\hline \begin{tabular}{|l|} 
Tahap II \\
Penerapan \\
Strategi \\
Berimbang
\end{tabular} & $\begin{array}{l}\text { 1. Menerapkan strategi membaca dan } \\
\text { menulis yang sesuai dengan } \\
\text { kebutuhan (modeled/ shared/ } \\
\text { interactive/ guided/ independent } \\
\text { reading and writring) } \\
\text { 2. Mengelola kelas secara preventif } \\
\text { dan kuratif } \\
\text { 3. Membimbing siswa untuk } \\
\text { membangun pemahaman } \\
\text { 4. Memberikan kesempatan siswa } \\
\text { untuk bertanya jawab }\end{array}$ & 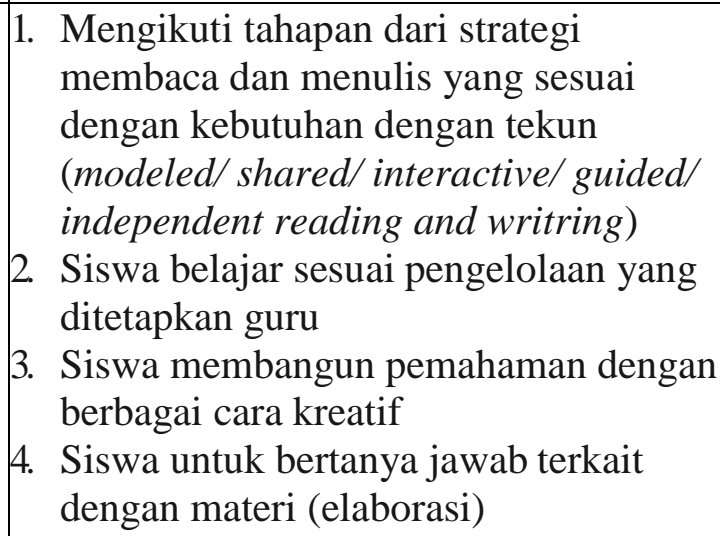 \\
\hline $\begin{array}{l}\text { Tahap III } \\
\text { Penyajian } \\
\text { Informasi }\end{array}$ & $\begin{array}{l}\text { 1. Memberikan tugas kreatif individu } \\
\text { dan kelompok } \\
\text { 2. Memberikan kesempatan bertanya } \\
\text { jawab } \\
\text { 3. Membimbing penyelesaian tugas } \\
\text { 4. Membimbing penyajian informasi }\end{array}$ & $\begin{array}{l}\text { 1. Menyimak dengan tekun tugas kreatif } \\
\text { individu dan kelompok } \\
\text { 2. Siswa bertanya jawab } \\
\text { 3. Siswa menyelesaikan tugas secara } \\
\text { kreatif } \\
\text { 4. Siswa menyajikan informasi melalui } \\
\text { karya kreatif baik lisan maupun tulis }\end{array}$ \\
\hline $\begin{array}{l}\text { Tahap IV } \\
\text { Refleksi }\end{array}$ & $\begin{array}{l}\text { 1. Membimbing siswa untuk berperan } \\
\text { dalam mengemukakan pendapat } \\
\text { terhadap karya teman } \\
\text { 2. Membimbing siswa dalam menulis } \\
\text { jurnal reflektif (tahap pertama } \\
\text { menuliskan apa yang terjadi/apa } \\
\text { yang dilihat/apa yang dialami/apa } \\
\text { yang dilakukan; tahap kedua } \\
\text { menuliskan apa yang baik/tidak } \\
\text { baik. Manfaat/tidak dari } \\
\text { pengalaman tersebut; tahap ketiga } \\
\text { menuliskan apa yang } \\
\text { seharusnya/sebaiknya dilakukan) }\end{array}$ & $\begin{array}{l}\text { 1. Siswa mengemukakan pendapat secara } \\
\text { aktif terhadap karya teman } \\
\text { 2. Siswa menulis jurnal reflektif (tahap } \\
\text { pertama menuliskan apa yang } \\
\text { terjadi/apa yang dilihat/apa yang } \\
\text { dialami/apa yang dilakukan; tahap } \\
\text { kedua menuliskan apa yang baik/tidak } \\
\text { baik. Manfaat/tidak dari pengalaman } \\
\text { tersebut; ketiga menuliskan apa yang } \\
\text { seharusnya/sebaiknya dilakukan) }\end{array}$ \\
\hline
\end{tabular}

Selanjutnya dilakukan uji coba terbatas terhadap prototipe model yang dirancang untuk pembelajaran literasi dasar siswa kelas awal. Uji coba dilakukan di SDN Golo kelas I, II dan kelas III. Jenis penelitian untuk ujicoba ini adalah penelitian deskriptif, yaitu mengimplementasikan model pembelajaran yang dikembangkan, kemudian melihat perbedaan hasil capaian belajar sebelum dan setelah diimplementasikan model pembelajaran. Ujicoba melalui penelitian deskriptif ini merupakan keterbatasan dalam penelitian karena tidak dapat melihat keefektifan penerapan model.

Rancangan pembelajaran untuk implementasi model disusun bersama-sama antara peneliti, guru, dan mahasiswa. Ujicoba implementasi model pembelajaran menunjukkan hasil capaian belajar sebagai berikut. 


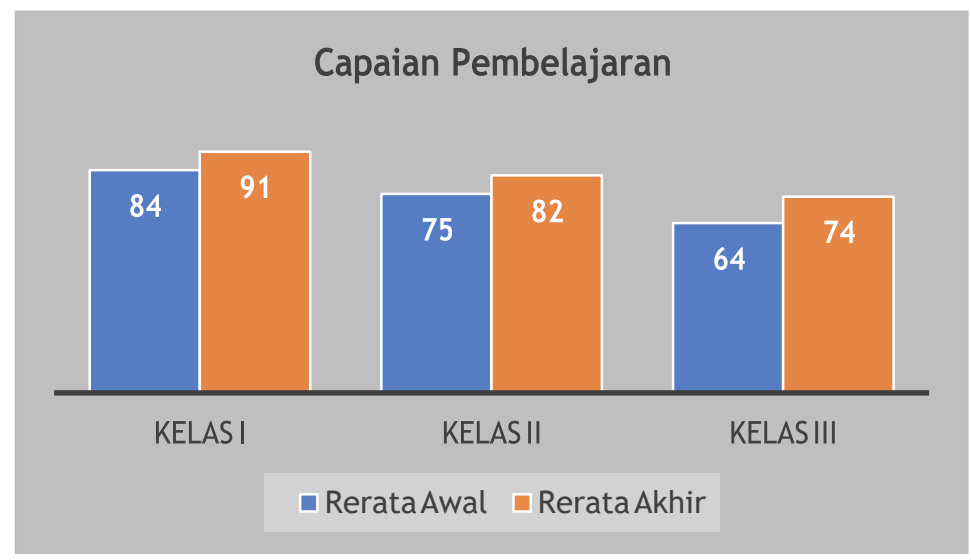

Gambar 1. Diagram capaian pembelajaran berdasar ujicoba implementasi model

Berdasarkan implementasi pelaksanaan langkah-langkah model pembelajaran yang telah dikembangkan, siswa diminta untuk memberikan responnya. Hasil angket respon siswa kelas I, II, dan III menunjukkan rerata skor dalam kategori sangat baik. Secara umum, partisipasi siswa sangat tinggi karena pembelajaran dilaksanakan dalam berbagai kegiatan yang kreatif, serta memberikan kesempatan yang sangat luas untuk siswa dalam mengembangkan kemampuan literasinya, yaitu menyimak, membaca, menulis, berbicara, dan berhitung.

Langkah-langkah dalam model yang dikembangkan, didesain dengan memaksimalkan pembimbingan guru, variasi kegiatan belajar secara individu dan berkelompok, dan aktivitas kerja siswa secara kreatif, baik pada tahap I eksplorasi sumber informasi, tahap II penerapan strategi berimbang, tahap III penyajian informasi, dan tahap IV refleksi. Kegiatan kreatif yang dirancang dalam perangkat pembelajaran sangat membantu siswa untuk mengembangkan kemampuan literasi dasarnya. Hal ini sejalan dengan pendapat Brown (2001) terkait dengan pembelajaran bahasa untuk anak yang mengemukakan bahwa prinsip mewujud-kan pembelajaran untuk peserta didik, khususnya anak-anak, yaitu fokus pada penekanan di sini dan sekarang, aktivitas harus didesain untuk mendapat ketertarik-an mereka secara langsung, pembelajaran perlu variasi kegiatan untuk tetap menjaga ketertarikan dan perhatian, guru perlu menjadi animated, hidup dan antusias mengenai subjeknya. Menimbang keadaan kelas di mana guru sebagai tokoh utama yang energinya akan sangat mempe-ngaruhi. Saat guru berpikiran apa yang dilakukannya terlalu berlebihan, anak-anak memerlukan hal yang dilebih-lebihkan tersebut untuk tetap melambungkan semangat dan kewaspadaannya, anak-anak memiliki banyak keingintahuan alami. Pastikan guru melangkah pada keingintahuan tersebut dan sebisa mungkin dilakukan karena itu membantu untuk menjaga perhatian dan fokus.

Selain hal-hal di atas, penerapan model pembelajaran ini juga menggunakan berbagai jenis media dan sumber belajar yang konkret, di antaranya buku-buku bacaan bergambar, denah sekolah, video, dan lain sebagainya. Pemanfaatan media dan sumber belajar tersebut sesuai untuk pembelajaran di kelas awal yang berada dalam perkembangan operasional konkret sebagaimana pendapat Santrock (2009) yang mengemukakan alternatif strategi mengajar yang sesuai untuk tahapan operasional konkret di antaranya adalah mendorong peserta didik untuk menemukan konsep dan prinsip dengan cara mengajukan pertanyaan yang relevan mengenai materi yang sedang dipelajari agar peserta didik dapat menjawab melalui pemikirannya sendiri; melibatkan peserta didik dalam tugas-tugas operasional, seperti penambahan, pengurangan, perkalian, pembagian, pengaturan, dan pengurutan dengan menggunakan materi 
konkret; merencanakan aktivitas yang membuat peserta didik mempraktikkan konsep hierarki klasifikasi; menciptakan aktivitas agar peserta didik dapat mengurutkan dan membalik urutan; selalu meminta peserta didik untuk memberikan alasan atas jawaban yang telah diberikan dalam memecahkan masalah; mendorong peserta didik untuk bekerja dalam kelompok dan bertukar pikiran satu sama lain; menggunakan peralatan dan bantuan visual ketika mengajarkan sesuatu yang kompleks.

\section{PENUTUP}

Model pembelajaran berbasis Balanced Literacy Approach bermuatan nilai-nilai karakter ini untuk mengembangkan kemampuan literasi dasar siswa kelas awal sekolah dasar. Adapun model pembelajaran yang dikembangkan terdiri atas 4 tahap kegiatan pembelajaran, yaitu tahap I eksplorasi sumber informasi, tahap II penerapan strategi berimbang, tahap III penyajian informasi, dan tahap IV refleksi. Hasil pengembangan model ini berdasarkan validasi ahli materi menunjukkan rerata skor 3,6 (kategori sangat baik) dan skor rerata validasi ahli pembelajaran sebesar 3,6 (kategori sangat baik). Hasil ujicoba implementasi model menunjukkan capaian rerata hasil belajar di kelas I sebesar 91 dari rerata kemampuan awal sebesar 84 . Rerata hasil belajar di kelas II sebesar 82 dari rerata kemampuan awal 75, dan di kelas III menunjukkan rerata hasil belajar 74 dari rerata kemampuan awal sebesar 64. Hasil angket respon siswa terhadap implementasi model pembe-lajaran di kelas I menunjukkan rerata skor 3,3 (kategori sangat baik), kelas II menunjukkan rerata skor 3,7 (kategori sangat baik), dan kelas III menunjukkan rerata skor 3,5 (kategori sangat baik). Secara umum, siswa dalam mengikuti pembelajaran sangat aktif karena dalam pembelajaran ini memberikan berbagai kegiatan literasi yang kreatif dan bervariasi.
DAFTAR PUSTAKA

Amri, S., dkk. (2011). Implementasi pendidikan karakter dalam pembelajaran. Jakarta: Prestasi Pustaka Raya.

Balitbang. (2010). Pengembangan pendidikan budaya dan karakter bangsa: Pedoman Sekolah. Jakarta: Kementrian Pendidikan Nasional.

Borg, R. W. \& Gall, M. (1989). Educational research: an introduction third edition, New York : Longman.

Brown, H. D. (2001). Teaching by principles an interactive approach to language pedagogy (second edition). New York: Longman.

Detik News. (2015). Pelaku kekerasan di $S D$ harus dibina. Berita diunduh tanggal $30 \quad$ Mei 2016 dari http://news.detik.com/berita/271821 6/dirjen-dikdas-pelaku-kekerasan-disd-bukittinggi-harus-dibina.

Klein, M.L., Peterson, S., \& Simington, L. (1991). Teaching reading in the elementary grades. USA: Allyn and Bacon.

Kompas. (2016). 400.000 Siswa SD Tak Naik Kelas.

http://www.pressreader.com/ indonesia/kompas/20161010/281505 045728724.

Pearson, P.D., Raphael, T.E., Benson, V.L., \& Madda, C.L. (2007). Balanced in comprehensive literacy instruction: Then and now. New York: GuildfordPress.

Santrock, J. W. (2009). Psikologi pendidikan. (Terjemahan Diana Angelica). New York: Mc Graw-Hill. (Buku asli diterbitkan tahun 2008).

Tompkins, Gail E. (2010). Literacy for the $21^{\text {St }}$ century a balanced approach. Boston: Allyn \& Bacon/ Pearson.

USAID. (2015). Buku sumber untuk dosen LPTK. Pembelajaran literasi di Sekolah Dasarl Madrasah Ibtidaiyah. Jakarta: USAID PRIORITAS. 
Wiedarti, P., dkk. (2016). Desain induk gerakan literasi sekolah. Jakarta: Direktorat Jenderal Pendidikan Dasar dan Menenngah. Kementerian Pendidikan dan Kebudayaan.

Zuchdi, D. (ed). (2011). Pendidikan karakter dalam perspektif teori dan praktik. Yogyakarta: UNY Press. 